\title{
Complete Distension and Complete Duration of Pharyngoesophageal Segment Opening During Swallowing
}

National Cancer Institute

\section{Source}

National Cancer Institute. Complete Distension and Complete Duration of

Pharyngoesophageal Segment Opening During Swallowing. NCI Thesaurus. Code C127320.

A finding of complete distension and complete duration of pharyngoesophageal segment opening during swallowing; no obstruction of flow. 